\title{
Urban public transport as a tool of sustainable mobility policy - the example of Poland
}

\author{
Paweł Gałka* \\ Krzysztof Grzelec** \\ Katarzyna Hebel*** \\ Eamonn Judge**** \\ Olgierd Wyszomirski*****
}

\section{Assumptions and objectives of sustainable mobility}

\section{Introduction}

The source of the concept of "sustainable mobility" is the concept of "sustainable development", formulated for the first time in the "Our Common Future" report of 1987, generally referred to as the "Brundtland Report". Attention was drawn to the need to comprehensively address the issues of sustainable development in a social, economic and environmental context. Such an approach has developed so much that in 2015, 193 countries adopted the United Nations 2030 Agenda, which included 17 sustainable development goals with related tasks, which are interdependent and indivisible. They strive to adopt policies that serve sustainable transport systems (Banister 2008, pp. 73-80). It was also assumed that the goal is to provide all people with access to safe, affordable, sustainable and easily accessible transport systems by 2030 , to increase the level of road safety, especially

* Paweł Gałka - MSc, University of Gdansk, Faculty of Economics, Department of Transportation Market, pawel.galka@ug.edu.pl

** Krzysztof Grzelec - prof. UG, dr hab., University of Gdansk, Faculty of Economics, Department of Transportation Market, krzysztof.grzelec@ug.edu.pl

*** Katarzyna Hebel - prof. UG, dr hab., University of Gdansk, Faculty of Economics, Department of Transportation Market, katarzyna.hebel@ug.edu.pl

**** Eamonn Judge - Leeds Business School, Leeds Beckett University, LS1 3HB, United Kingdom

***** Olgierd Wyszomirski - prof. dr hab., University of Gdansk, Faculty of Economics, Department of Transportation Market, olgierd.wyszomirski@ug.edu.pl 
through the development of public transport, paying particular attention to the needs of vulnerable groups, women and children, people with disabilities and the elderly. The agenda applies to all countries, taking into account the different realities, opportunities and levels of development of each individual, as well as respecting the policies and priorities adopted in each country. In the Polish state transport policy for 2006-2025, in relation to urban transport, the main tasks were to support city self-governments in the implementation of the sustainable development policy and to reverse the unfavourable trends in spatial transformations and the development of transport systems and to sustain positive changes. Among the instruments of the state policy concerning transport in cities, the following were indicated:

- introducing the obligation to formulate transport policy,

- introducing traffic and parking analysis for spatial development plans,

- promoting integration solutions in urban transport to encourage the creation of intermodal systems (interchange nodes, "park and ride" systems), common timetables, uniform tariff systems, and the introduction of tickets valid for all means of transport,

- promoting rail transport,

- supporting the demonopolisation of the transport services market,

- supporting technical and organisational activities for the improvement of road safety,

- promoting bicycles,

- creating incentives to adapt transport systems for people with disabilities,

- promoting innovative technical solutions, e.g., in the field of traffic control,

- supporting and disseminating activities for mobility management in the sense of encouraging people to give up unnecessary car journeys and make them "friendly" means of travel or to make trips outside of peak times,

- using social education for promotion, including an information and advertising campaign, "mobility culture", i.e., attitudes that encourage pedestrian traffic and the use of bicycles and public transport, and the attitude of responsible, self-limiting use of a passenger car (Banister 2004, pp. 611-632).

The analysis of the Polish state transport policy for 2006-2025 in connection with the goals of sustainable development set out in the United Nations 2030 Agenda allows us to conclude that in Poland legal grounds have been created for urban public transport to be a tool for sustainable development. It is also worth noting that sustainable development is a very broad concept which results from, among others, sustainable urban mobility. 
Sustainable urban mobility is an issue encompassing transport, spatial planning and social issues. Sustainable mobility provides an alternative paradigm within which to investigate the complexity of cities, and to strengthen the links between land use and transport (Epomm 2010).

Mobility is essential to ensure freedom of movement and quality of life. Mobility planning covers all types and forms of transport in the city, both public transport, as well as private, passenger and freight, motorised and non-motorised transport. Sustainable transport is also achieved by reducing transport needs. Some transport needs may even be reduced at the urban planning stage, by mixing land uses and avoiding the creation of monofunctional areas. In addition, some journeys do not have to be undertaken, because they can be replaced by modern technologies, e.g. through internet shopping or contacts using instant messaging (e.g. Skype). The impact of information and communication technologies on transport is a complex issue requiring research on the mutual complementarity between transport and ICT (Information and Communication Technologies) (Goldman, Gorham 2006, pp. 261-273).

Mobility management is an activity related to planning, organizing, coordinating and controlling the flow of people and goods using the available human, financial, material and information resources. The main purpose of sustainable mobility is to influence attitudes, demand and transport behaviour to encourage the use of alternative travel modes to the private car.

As part of the EU MAX project (UITP 2002), it was established that mobility management is focused on demand and not on supply. The basis of mobility management is "soft" measures, such as information and communication, the organisation of services and the coordination of the activities of various partners. Their aim is to improve the effectiveness of "hard" measures, and the characteristic feature is that in comparison with "hard" measures, they do not require large financial outlays. Attention was paid to the need to develop separate instruments that influence the change in transport behaviour for various groups of inhabitants. In recent years there were four clusters of activity: New Mobility, City Logistics, Intelligent System Management and Livability, with particular emphasis on innovation (Potocki, Brocato 1995, pp. 402-412).

Successful public transport requires a combination of measures that all exert control over car use with the development of competitive public transport services. The conditions for successful public transport are (Hughes 2012):

- ease of access on foot to public transport and the potential speed and regularity of public transport are vital conditions if it is to compete successfully with the car,

- the most attractive and efficient public transport networks serve dense conurbations and chiefly use dedicated rail modes, 
- limiting the number of parking spaces in city centres is an important tool in a policy for sustainable mobility and public transport prioritisation: cities in which public transport is used by large numbers of people provide few parking spaces in their centres.

Restrictions on the use of private cars are necessary. UITP (International Association of Public Transport, from the French: L'Union internationale des transports publics) recommends (UITP 2002):

- limiting the number of parking spaces in city centres,

- extending roadside pay-parking and increasing parking charges for non-residents both at the roadside and in public car parks,

- stepping up parking controls and improving the efficiency with which parking fines are collected,

- discouraging the practice of offering staff a company car and free parking at their place of work,

- re-assigning road space in favour of pedestrians, bicycles and reserved rights-of-way for public transport vehicles,

- confining city-centre access to buses, tramways, residents' vehicles and delivery vehicles (at certain times),

- introducing urban road pricing if the measures described earlier prove to be inadequate.

The above recommendations were reflected in Polish documents such as the National Urban Policy 2023 (Wolman 2004, pp. 639-665). In the part dedicated to urban transport and mobility, it was emphasised that in order to solve transport problems in cities, action should be taken on both the supply and demand sides. In particular, there is a need for a significant improvement in public transport in functional city areas as a supply solution. The main priority in terms of demand must be efforts to change transport behaviour, and in particular, to reverse the trend of increasing dependence on the daily use of a passenger car for travelling in an urban area. In addition, the role of integration is emphasised, including the organisation of public transport management, organisation of interchange nodes (also considering alternative means of transport such as bicycles and scooters), ensuring easy access to stops, tariff and scheduled integration, construction of "park and ride" systems (Wolman 2004, pp. 639-665). Therefore, it can be assumed that sustainable mobility and sustainable mobility management in the "European" sense is properly reflected in Polish legal regulations.

To respond to the massive global trend of urbanisation, in October 2016, the Third United Nations Conference on Habitats was held, which adopted the UN's New Urban Agenda (NUA) (Dreschler 2005, pp. 17-28). 
The NUA is a new vision of cities and municipalities for the next 20 years. This document sets a new global standard for sustainable urban development and helps to rethink and manage urban life. The NUA is part of 17 key sustainable development goals (SDGs) related to city development, quality of life and social equality. The main areas of the NUA relate to the specific goals of SDG No. 11, which is "to make cities and human settlements inclusive, safe, resilient and sustainable" (Holmgren 2007, pp. 1021-1035). With no legal force, the NUA is merely a declaration designed to express a joint position of the stakeholders. Despite that, it does create a language in which urban issues and urban developments over the coming decades will be discussed.

The COVID-19 pandemic has had a negative impact on the functioning of public transport and reduced its role as the most important segment of services offered in the framework of sustainable mobility. Passenger restrictions on the use of public transport vehicles have not only shifted modal split, but also created financial problems as a result of reduced ticket revenues. In Gdańsk, the public transport authority stated that ticket revenues in 2020 will be $40 \%$ lower compared to 2019 .

That economic condition of public transport may make it necessary to review the strategies of public transport companies and cities in terms of the pace and directions of achieving the goals of sustainable mobility. Assuming that the problems related to the pandemic will be resolved by the end of 2020, a delay in the implementation of specific investment activities in public transport should be expected, as a result of the need to increase the financial supply of current transport services. An increase in subsidies will be required, despite the limitation of the transport offer by transport organizers. These restrictions should be introduced in a way that does not compromise the achievement of the goals of sustainable mobility within the assumed time.

The authors' own research carried out in Gdynia and adjacent communes allowed us to conclude that subsidies for public transport in 2021, as a result of a decrease in demand, will have to increase by from a few to several percent depending on the commune. Paradoxically, the best economic situation of public transport occurs in rural communes, where the lowest number of passengers uses services per vehicle kilometers travelled ( $\mathrm{vkm}$ ). In these municipalities, the reduction in demand caused by COVID-19 is the least disadvantageous for the budget, because public transport costs were covered by subsidies to a much greater extent there than in cities before the pandemic.

\section{Hypotheses and goals of the article}

The following research hypotheses were put forward in this study:

- achieving the objectives of sustainable mobility through the development of the public transport offer requires the use of modern management methods and consistency in the implementation of the actions undertaken, 
- it is necessary to identify the main attributes of public transport that determine the use of this type of transport and to finance those elements of the transport offer that correspond to these attributes.

Taking the above research hypotheses, the aim of the article is to assess the role of public transport as an element of sustainable mobility and to explain the reasons for the unsatisfactory effects of policy in Poland. Achieving the goals of sustainable mobility requires the integration of the passenger transport offer, understood today as Mobility as a Service (MaaS), i.e. the integration of activities of various entities involved in providing public transport services. Meanwhile, in Poland, in some cities, there is still a problem with the integration of the public transport offer. A review of the literature on the effectiveness of sustainable mobility policy shows that research focuses on the objectives, tools and monitoring of results. International experience in the implementation of sustainable mobility most often presents the so-called "best practices". This article tries to analyse and explain the causes of different results in Poland.

\section{Achieving goals through process management}

Analysis of the effectiveness of management processes allows for the identification of five principles determining the achievement of the assumed goal as part of the continuous improvement of the implemented activities. These are: comparative analysis (benchmarking), leadership, employee engagement, process improvement and customer focus (Eboli, Mazzulla 2008, pp. 509-523).

It is indicated that improving the effectiveness of local authorities requires (Redman, Friman, Garling, Hartig 2013, pp. 119-127):

- understanding and identifying the needs of residents,

- implementing programs and services that will satisfy the residents,

- collecting and analysing information about the effectiveness of measures taken to improve results,

- using data effectively to inform in a comprehensible way how to make political decisions,

- conducting an open policy of implemented measures in municipal units and towards the public,

- encouraging the residents to express their opinions and co-decide in the implementation of decision-making processes.

Changing the approach to the tasks of public authorities within the framework of New Public Management (NPM) is done by setting targets and controlling the effects of their implementation (management by results), and increased 
innovation. The emphasis on results is due to the conviction that public sector organisations do not pay attention to the quality of services provided, but instead follow the logic of budgetary thinking. The introduction of the evaluation of the implemented activities should be equivalent to implementing clear and measurable standards and performance indicators. The expected and consistent results are favoured by the use of competition mechanisms (privatisation, outsourcing). NPM is largely based on the concept of public choice, which perceives the individual as a consumer of services offered by public administration, with choices (Zarząd Komunikacji Miejskiej w Gdyni). This makes it possible to expand the list of mobility management instruments with solutions for the organisation and management of public transport.

In Poland, with regard to urban transport, including public transport, the principles of NPM were implemented at the beginning of the 1990s. The criticism of NPM (New Urban Agenda 2020) and the inflow of significant financial resources after the country's accession to the European Union stopped the processes of change. In many cases, traditional budgetary management was reinstated, the priority of which is the implementation of annual plans. But the primacy of budget planning and the controlling of budget outcomes is not conducive to achieving sustainable mobility objectives.

From the point of view of the efficiency of measures in the field of sustainable mobility, strict application of NPM rules is essential. The emphasis on results becomes the determinant of organisational solutions. Meanwhile, in Poland, especially in polycentric agglomerations, not even one association of transport organizing and coordinating passenger transport has been appointed. In Upper Silesia, for many years there were two municipal associations, and it was only in 2017 that an attempt was made to create a single metropolitan union based on the national parliament's law. In the Gdańsk agglomeration, there are two public transport authorities (contracting seven operators), and three operators were also performing the organizer's functions (including two railways). A metropolitan association was also established, but its competences were limited only to implementing metropolitan fares (this is the sixth type of fares system in force in the Gdańsk agglomeration). Recently, another entity has been set up whose aim is to introduce a ticketing system in the region, which will be based on mobile devices. Thus, the activities of the authorities can be seen to exhibit a lack of coordination caused by the lack of a clear vision of the future, primarily a lack of emphasis on results, an excessive focus on budgetary accounting principles and large spectacular investments. There is also a lack of consistent implementation of adopted strategic documents that contain appropriate measures and results indicators. 


\section{Attributes of services and decision effectiveness indicators in managing the public transport services}

Public transport in cities is considered a strong and viable alternative to the private car mode (United Nations 2015). The basis for efficiency in the implementation of sustainable mobility policy is the change in residents' transport behaviour, leading to an increase in the share of trips by public transport, bicycles and on foot. Considering the increase in the number of passengers in public transport in projects concerning sustainable mobility, implemented in the European Union countries, as a measure of the effectiveness of operations, is not, in the authors' opinion, the right approach. An increase in passenger numbers can be achieved within the same share of public transport in modal split by increasing the number of transfers. Then, statistically, the number of passengers will increase, but without the expected change in transport behaviour.

Eboli and Mazzulla (2008) consider public transport prices and frequency as the most important qualitative characteristics for users. However, in their research, they relied mainly on low-income students, who represent a specific market segment, so they are not representative of the population of public transport passengers or residents.

Redman et al. (2013) list two groups of public transport attributes expected by residents:

- physical (reliability, frequency, speed, availability, price, information, ease of change, vehicle condition),

- perceived (travel comfort, travel safety, ease of use, aesthetics).

The number of attributes subjected to research and analysis of their validity for residents may vary depending on the purpose of the study - practical or academic. For example, surveys of transport users' preferences and transport behaviour conducted regularly since 1994 by the Public Transport Authority in Gdynia (Poland), are related to practical purposes, and include ten attributes (Wolmann 2004). On the other hand, the research carried out by the Cracow University of Technology in order to achieve academic goals (Dreschler 2005) led to the identification of 26 attributes. A review of qualitative indicators was also made by Pticina (2011), recommending the development of standards for the quality of public transport services in Riga (Latvia).

The importance of individual attributes of public transport for residents varies depending on many factors, for example, travel distance (Eboli, Mazulla 2008) and the location of the area of residence in relation to the centre, socio-professional status (Redman, Friman, Garlin, Hartig 2013), age (Zarząd Komunikacji Miejskiej w Gdyni 2016), lifestyle (Starowicz 2001), and frequency of using public 
transport. The impact of each factor on the choice of public transport depends not only on the importance of the given attribute, but also on the degree to which it is fulfilled. There may be significant discrepancies between the level of quality provided and assessed by the organizers and operators of public transport and the level of quality perceived by its users. Rietveld (2005) claims that public transport service providers systematically evaluate too highly the quality of services they provide. One of the best-known indices is Servqual, developed for the needs of marketing. It depends on the subjective measurement of the difference between expectations and the perception of quality in five dimensions common to all services (Reichald, Holz-Rau 2015). The level of satisfaction with the implementation of individual attributes and their significance change with the implementation of specific solutions aimed at bridging the gap between the expected quality and the quality offered (Carlsson 2003).

In cities and agglomerations in Poland, the most important attributes of public transport include those associated with the time of travel (Bryniarska and Starowicz 2010). In some cities in Poland for several years, the most important aspects include directness of connections (journeys without transfers), punctuality, frequency and availability. The impact of attributes on the increase in the attractiveness of public transport services was investigated by Redman et al. (2013).

The effectiveness of actions taken by public authorities in the field of sustainable mobility should be monitored and periodically evaluated using a set of indicators. Indicators are variables based on specific measurements, reflecting as closely as possible the phenomenon being analysed (Joumard and Gudmundsson 2010). Indicators are variables selected and defined to measure progress towards the goal (Rietveld 2005).

When analysing the effectiveness of actions undertaken, it should be remembered that making mobility sustainable requires the reconciliation of conflicting interests. In this context, Nykvist and Whitmarsh (2008) pointed to three areas of innovation: transport technologies, the product-to-service shift, and mobility management, whose development can lead to more sustainable transport.

Gillis, Semanjski and Lauwers (2016) carried out an overview of 22 indicators that cover different aspects of sustainable mobility, and which are applicable in different social and economic contexts around the world.

A system of indicators of sustainable mobility was proposed by Haghshenas and Vaziri (2012), who distinguished three groups according to the criterion of impact on specific socioeconomic areas: a transportation environmental impact indicator, a transportation economic impact indicator, and a transportation social impact indicator. These indicators were introduced to carry out a global cities comparison.

The sustainable mobility evaluation based on an index calculated through a weighted multi-criteria combination procedure was proposed by Joumard and 
Gudmundsson (2010). They proposed a set of indicators to evaluate mobility in urban areas based on the three dimensions of sustainability, i.e., environment, economics, and social aspects. The adaptability of this set of sustainable mobility indicators was analysed for, among others, the Lyon conurbation (Litman 2008).

A set of nineteen indicators to comprehensively describe sustainable mobility in cities was identified in Methodology and Indicator Calculation Method for Sustainable Mobility (Nykvist, Whitmarsh 2008). They make it possible to assess the performance of cities worldwide, at any stage of economic development.

Finally, it should be stated that there is no globally applicable set of tools and indicators that ensure a holistic evaluation or that facilitate the replicability of best practices. Due to the limited access to some of the proposed indicators and the need to continuously update them, it is recommended to establish a mobility observatory in cities (Gilis, Semanjki, Lauwers 2016). It is also important to distinguish indicators that determine the temporal durability of sustainable mobility in cities through changes in transport behaviour.

\section{Research on the effectiveness of sustainable mobility policy in relation to public transport in Poland}

\section{Methodology}

This article analyses the effectiveness of public authorities' activities in the field of sustainable mobility in six large cities in Poland. Four of them (Warsaw, Kraków, Poznań and Wrocław) are monocentric agglomerations, and two (Gdańsk and Gdynia) are polycentric agglomerations. Since most Polish cities have developed sustainable mobility policies in the form of appropriate documents in the last five or six years, it would be premature to assess the activities undertaken to achieve the goals of sustainable mobility contained in these documents. For this reason, the analysis includes cities which adopted documents in the 1990s under the title transport policy, where the objectives correspond to the main objectives of sustainable mobility. The criterion for the selection of cities was also the fact that since 2010, they have carried out surveys of residents' demands and transport behaviour which allow the assessment of the most important indicator of sustainable mobility, namely, modal split. The research was carried out as a Traffic Complex Survey (five cities) or a study of residents' preferences and transport behaviour (one city).

The Traffic Complex Survey (TCS) examined the volume and speed of vehicle traffic, the structure of vehicle types and freight, the modes of travel, travel destinations, and the reasons for choosing specific ways of travelling. The main 
goal of the TCS was to diagnose the transport situation in cities and to build a traffic model that allows the forecasting of changes in traffic depending on the adopted scenarios regarding the transport policy being implemented.

The public transport authorities in Poland rarely conduct comprehensive marketing research on passenger preferences and transport behaviour. The only entity that performs a regular study of this type (every 2-3 years) is the Public Transport Authority in Gdynia (ZKM). The subject of the research is transport behaviour, enabling the identification of modal split, residents' transport preferences, including the ranking of public transport attributes, reasons for using a private car, bicycle, car sharing, or public transport, and the assessment of the quality of public transport services.

Particular analytical limitations relate to the use of raw and processed data due to the scope of the research carried out in individual cities, and the way data is aggregated varies. In addition to the differing scope of analyses, another problem is the representativeness of the research results. Representativeness means carrying out research on a properly selected sample. Thus, in order to obtain representative test results, a random selection of the sample should be applied where a random choice determines which unit will be selected. The highest statistical efficiency is characterised by stratified samples. They show the smallest standard error of assessment. Stratified samples with the highest statistical efficiency are obtained when the strata are as homogeneous as possible (Haghshenas, Vaziri 2012).

The possibility of choosing a representative sample for research is limited in Poland. It is determined by the personal data protection law impeding, and, in some cases, excluding the possibility of obtaining a list of the surveyed population from which the sample will be drawn. ZKM in Gdynia uses an anonymous list (without names and surnames) of residents aged 16-75, obtained from the city office. Problems with the implementation of the random sample based on the list of residents prompted the use of the random route selection method in TCS. Domestic households are chosen randomly, and respondents are selected for research in proportion to their sex and age in the area studied. However, there are certain doubts about the representativeness of a sample obtained in this way (Campos, Ramos, Silva Correia 2009).

In recent years, Poland has attempted to extend the research carried out every ten years as part of the national census of the transport behaviour of residents. Research conducted on a sample of $20 \%$ of households on a national scale focusses on commuting to work and the choice of mode of transport for these journeys (Nicolas, Pochet 2003).

The problem with the implementation of random sampling in the study of transport behaviour (regardless of the method used to select the sample) is the difficulty in reaching people in the highest socioeconomic groups and, consequently, 
with the highest mobility indicators. It should, therefore, be assumed that the share of users of private cars with the highest mobility is undervalued in every study.

In analysing the effectiveness of measures from the point of view of sustainable mobility goals, we used statistical data, the results of research on transport demand and behaviour, and TCS. For the analysis, seven indicators were adopted:

- the number of inhabitants - as a starting point for analysis,

- modal split,

- the number of vehicle-kilometres in public transport (new lines, increased frequency),

- changes in the structure of public transport vehicles,

- changes in infrastructure that improve the quality of public transport (length of bus lanes, number of interchanges including park and ride $\mathrm{P} \& \mathrm{R}$ or bike and ride $\mathrm{B} \& \mathrm{R}$ ),

- the length of bicycle routes,

- the number of registered cars per 1000 inhabitants.

The main criterion is the modal split. Other indicators, referring to the Methodology and Indicator Calculation Method for Sustainable Mobility, were used to explain the changes in modal split. Comparative analysis was used in the research.

Part of the assessments presented, especially concerning the public transport offer in the Gdańsk agglomeration, is the result of research carried out by the participant observation method. All but one of the authors of this article are not only research employees, but also practitioners working on a day-to-day basis in the Public Transport Authority in Gdynia and the Gdańsk Bay Metropolitan Public Transport Association.

Drawn from the comparative analysis, the conclusions were verified and deepened using the case study of the Gdańsk agglomeration (Gdańsk and Gdynia).

\section{Materials}

The materials used in the study were obtained from reports available on the websites of the cities and the research organizers. Reports on preferences and transport behaviours of the inhabitants of Gdynia, available on the Public Transport Authority website, were used to the greatest extent. The materials obtained from the Central Statistical Office regarding nationwide research on this subject, unfortunately, carried out only once so far, should also be considered valuable.

All data from these sources are public in Poland; they do not require special consent for their use and dissemination. It is only necessary to mention their source, which the authors did as part of the footnotes and references. The authors participated in the study of transport preferences and behaviour in Gdynia; therefore, the data from these studies are used to a greater extent. 


\section{Analysis of results}

Selected demographic and transport indicators are presented in Table 1. The population in individual cities ranges from 246,000 to $1,764,000$. In the period from the adoption of the last transport policies (1999), the number of inhabitants increased in two cities (Warsaw and Kraków), in three it decreased (Wrocław, Poznań and Gdynia) and in one (Gdańsk), it remained unchanged (Table 1). Regardless of population changes, in all cities forming these agglomerations, there is an unfavourable process of suburbanisation, which extends the time to commute to work and education.

Table 1. Selected demographic and transport indicators for the cities analysed

\begin{tabular}{|l|c|c|c|c|c|c|c|}
\hline \multicolumn{1}{|c|}{ Indicator } & Year & Warsaw & Kraków & Wroclaw & Poznań & Gdańsk & Gdynia \\
\hline $\begin{array}{l}\text { Number of residents } \\
\text { [in thousands] }\end{array}$ & 1999 & 1714 & 755 & 643 & 584 & 464 & 253 \\
\cline { 2 - 8 } & 2017 & 1764 & 767 & 639 & 539 & 464 & 246 \\
\hline $\begin{array}{l}\text { vkm (excluding under- } \\
\text { ground and railway) } \\
\text { [in thousands] }\end{array}$ & 1999 & 139,832 & 61,815 & 42,195 & 33,523 & 28,311 & 19,083 \\
\cline { 2 - 9 } & 2017 & 167,263 & 57,888 & 40,378 & 38,789 & 31,428 & 19,758 \\
\hline $\begin{array}{l}\text { length of bus lanes } \\
{[\mathrm{km}]}\end{array}$ & 1999 & 2.2 & 0 & 0 & 0 & 0 & 0 \\
\cline { 2 - 9 } & 2017 & 66.0 & 27.9 & 26.5 & 15.3 & 3.3 & 3.1 \\
\hline \multirow{2}{*}{ number of P\&R nodes } & 1999 & 0 & 0 & 0 & 0 & 0 & 0 \\
\cline { 2 - 9 } & 2017 & 14 & 3 & 7 & 0 & 9 & 4 \\
\hline \multirow{2}{*}{$\begin{array}{l}\text { length of bicycle } \\
\text { routes km } \\
\text { /10 000 km } 2\end{array}$} & 2011 & 5,641 & 3,305 & 6,758 & 4,009 & 3,436 & 2,811 \\
\cline { 2 - 9 } & 2017 & 10,395 & 6,766 & 8,534 & 6,682 & 6,661 & 4,381 \\
\hline $\begin{array}{l}\text { average age of city } \\
\text { buses }\end{array}$ & 1999 & 11.0 & 8.0 & 11.0 & 10.0 & 13.0 & 12.0 \\
\hline & 2017 & 8.0 & 6.0 & 10.0 & 7.0 & 9.0 & 11.0 \\
\hline $\begin{array}{l}\text { number of registered } \\
\text { cars / 1 000 inhabi- } \\
\text { tants }\end{array}$ & 2009 & 533 & 451 & 480 & 507 & 465 & 440 \\
\cline { 2 - 8 } & 2017 & 715 & 610 & 659 & 690 & 593 & 584 \\
\hline
\end{tabular}

Source: Główny Urząd Statystyczny Bank Danych Lokalnych, 2016. Izba Gospodarcza Komunikacji Miejskiej, Komunikacja miejska w liczbach. Dane za 12 miesięcy 2017 r., Warszawa 2018.

Between 1999 and 2017, two cities recorded a reduction in public transport vehicle- kilometres, and in the remaining ones, an increase from $3 \%$ to $19 \%$. In Warsaw, leaving aside the development of the underground, the number of vkm of ground transport increased by $19 \%$. This was caused mainly by the extension of the public transport offer to areas covered by suburbanisation processes. The number of vkm in Poznan increased by 16\%.

Since 1999, as a result of the objectives of the authorities, individual cities have implemented their transport policies with varying degrees of intensity and consistency. In 1999, bus lanes existed only in Warsaw, with a length of $2.2 \mathrm{~km}$. After 19 years (2018), $2.2 \mathrm{~km}$ had grown to $66 \mathrm{~km}$. The lowest length of bus 
lanes created $(3 \mathrm{~km})$ is in Gdynia, which is one-seventh the size of Warsaw. Not many more bus lanes have been created in Gdańsk, which is the largest city in the Gdańsk agglomeration. Apart from Warsaw, the number of P \& R nodes is relatively small. For comparison, there are $28 \mathrm{P} \& \mathrm{R}$ nodes within the administrative borders of Berlin. Most of the P \& R nodes in the Gdańsk agglomeration were established at the same time as the construction of a new railway line (Pomeranian Metropolitan Railway).

The growth of bicycle routes is significant in the cities analysed. Since 2011, there has been an increase in the length of bicycle routes, varying between $26 \%$ and $105 \%$. In Warsaw, the route density index in 2015 was $0.88 \mathrm{~km} / \mathrm{km}^{2}$, and the share of trips by bicycles was 3\%. Meanwhile, in Gdańsk in 2016, the corresponding figures were, respectively, $2.16 \mathrm{~km} / \mathrm{km}^{2}$ and $6 \%$. By comparison, in Berlin in 2008 , the share of bicycle trips was $13 \%$ (Graviter, Forzano 2019) and the route density index $0.69 \mathrm{~km} / \mathrm{km}^{2}$. Based on the data quoted, it is difficult to draw unambiguous conclusions. It can be assumed that the increase in the share of cycling trips in given conditions, determined by lifestyles and the perceived role of the car in society, occurs after reaching a certain level of density of the cycling network in a given city. The increase in the share of bicycle trips, including the substitution of private car trips, however, is a complex problem (Rada, Martin 2014), and infrastructure is only one of the variables determining the change in transport behaviour. The example of New York indicates that bike lane investments tend to impact non-commuters more than commuters (Bauer 2015). Also, the conditions for using cars and bicycles in the city (GUS 2016) and the perceived (subjective) rather than objective accessibility to the bicycle infrastructure (IGKM 2018) affect the choice of a given means of transport.

In Poland in 2007-2013, a total of PLN 17,411 million was allocated to implement investment projects in public transport, including PLN 8,952 million from EU funds (Berlin.de 2019). At the beginning of the transformation period in Poland, its cities, compared to the cities of developed countries (EEC, the USA, Australia, Japan), were characterised by favourable conditions for the development of sustainable mobility. The number of private cars per 1,000 inhabitants at the beginning of the transformation period in Poland was 128. In 2017, this indicator had increased to 586 (WBCSD 2015). The share of public transport in modal split in Poland in the 1970s was 90-92\%. In the 1990s, it decreased to 60\% (Fishman, Washington, Haworth 2014). Despite completed infrastructure and rolling stock investments in public transport, the number of private cars in Polish cities is constantly increasing, and the share of public transport in the modal split is falling below $50 \%$ (see Table 2). The average age of cars registered with a valid technical inspection certificate is 13.2 years in Poland. Sixty-four percent of cars first registered in Poland in 2017 were used vehicles. Ninety of them are cars older than four years. (Xu, Chow 2018, pp. 1-20). 
Table 2. Modal split in selected cities in Poland (percentage)

\begin{tabular}{|l|c|c|c|c|c|c|}
\hline \multicolumn{1}{|c|}{ Modal split } & $\begin{array}{c}\text { Warsaw } \\
\mathbf{2 0 1 5}\end{array}$ & $\begin{array}{c}\text { Kraków } \\
\mathbf{2 0 1 3}\end{array}$ & $\begin{array}{c}\text { Wroclaw } \\
\mathbf{2 0 1 8}\end{array}$ & $\begin{array}{c}\text { Poznań } \\
\mathbf{2 0 1 3}\end{array}$ & $\begin{array}{c}\text { Gdańsk } \\
\mathbf{2 0 1 6}\end{array}$ & $\begin{array}{c}\text { Gdynia } \\
\mathbf{2 0 1 8}\end{array}$ \\
\hline Walking & 17.9 & 28.4 & 24.2 & 13.0 & 20.8 & 10.9 \\
\hline Private car & 31.7 & 33.7 & 41.4 & 38.7 & 41.2 & 51.5 \\
\hline Public transport & 46.8 & 36.3 & 27.6 & 42.0 & 32.1 & 35.6 \\
\hline Bicycle & 3.1 & 1.2 & 6.3 & 4.0 & 5.9 & 1.6 \\
\hline Other & 0.5 & 0.2 & 0.5 & 2.3 & 0.0 & 0.4 \\
\hline
\end{tabular}

Source: Carse A., Goodman A., Mackett R.L., Panter J., Ogilvie D. (2003), The factors influencing car use in a cycle-friendly city: The case of Cambridge. "Journal of Transport Geography", p. 28; Dill J., Voros K. (2007), Factors Affecting Bicycling Demand: Initial Survey Findings from the Portland, Oregon, "Region. Transportation Research Record"; Raport o stanie komunikacji miejskiej w Polsce za lata 2000-2012 (2013), Warszawa. Available online: http://docplayer.pl/5735559-Raport-o-stanie-komunikacji-miejskiej-w-polsce-w-latach-2000-2012.html (accessed: 10.01.2019); Suchorzewski W., Rozkwitalska C. (1997), Raport o stanie komunikacji miejskiej w 1996 roku, Sterowanie i zarzadzanie ruchem w komunikacji miejskiej, Kraków. Available online: http://www. igkm.pl/site/publikacje/pub_raport96.pdf (accessed: 10.08.2019); Samochody osobowe zarejestrowane w Polsce (2017), Warszawa. Available online: http://www.cepik.gov.pl/dla-obywateli/usluga-statystyczna (accessed: 10.08.2019); Warszawskie Badanie Ruchu 2015 wraz z opracowaniem modelu ruchu. Synteza (2016). Available online: http://transport.um.warszawa.pl/sites/default/files/ WBR 2015 SYNTEZA POL.pdf (accessed: 7.01.2019).

The data on the modal split in Polish cities presented in Table 2 should be considered with caution. These results, as previously stated, are derived from a different research methodology and sample selection method (Warszawskie Badanie Ruchu 2016).

The modal split has changed unfavourably in Polish cities compared to cities in the western part of the European Union. Meanwhile, UITP data (Mobility in Cities 2018) indicates that the share of public transport in the modal split in the cities of the most economically developed countries increased in the years 1995-2012 from 34.1 to $39.7 \%$.

While in cities in the western part of European Union the share of public transport has actually increased, in Poland (Figure 1 and Table 2), despite the investments made in the years 2004-2018, it has decreased.

The standard of public transport services in Poland, after completion of certain infrastructural investments, does not fully meet the expectations of residents (mainly those using cars) and consequently does not ensure the expected results in achieving the goals of sustainable mobility policy.

In the transport plan for Warsaw, the ranking of transport priorities was not presented on the basis of surveys of residents; they were simply listed. Warsaw is the only city in Poland with an underground railway system (Urząd Miasta Warszawa 2016). There are $66 \mathrm{~km}$ of bus lanes in the city's public transport network (the longest bus lane network in Poland). An integrated ticket for buses, trams, the underground and city rail (suburban rail network) is offered. On all of 
these modes of transport, the same entitlements to reduced fares apply, which is an exceptional situation in Poland. These factors and, in particular, the integration of public transport, including the underground, may explain its relatively high share $(46.8 \%)$ in the overall modal split. The extensive and integrated offer of public transport in Warsaw did not, however, stop the decreased share of public transport and the increased share of private cars in the modal split.

Figure 1. Modal split changes in selected cities of the European Union in 2002-2019 (percentage)

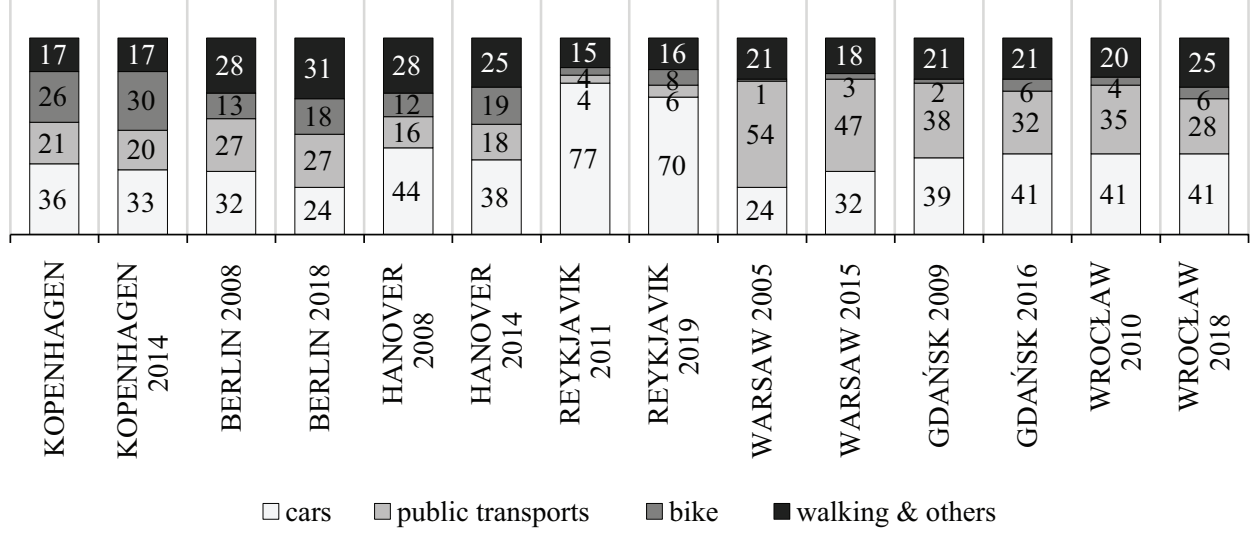

Source: Kompleksowe badania ruchu w Krakowie (2013). Available online: https://www.bip.krakow.pl/zalaczniki/dokumenty/n/207255/karta (accessed: 10.01.2019); Kompleksowe badania ruchu we Wroctawiu i otoczeniu. (2018). Available online: http://bip.um.wroc.pl/artykul/565/37499/kompleksowe-badania-ruchu-we-wroclawiu-i-otoczeniu-kbr-2018 (accessed: 7.02.2020).

In Krakow, based on survey research, it was concluded that the most important priorities that should characterize public transport are listed in the following order: punctuality, regularity (understood here as the rhythmic intervals between departures of vehicles of different lines in the same direction), directness, frequency and time spent on a vehicle. All these factors affect the total travel time. At the same time, the majority of Krakow residents (37\%) declared that fast journeys by public transport (avoiding congestion) would prompt them to give up using their cars. There are $26.5 \mathrm{~km}$ of bus lanes in the public transport network (Main statistical office 2017), but they constitute only $2 \%$ of the total length of bus routes (Kompleksowe badanie ruchu w Krakowie 2013). In the absence of an underground and surface city rail system, such a low share of bus lanes in the overall network of bus routes is not able to provide competitive public transport services in relation to a private car in terms of travel time. Trams offer better services. The separated tramway tracks account for $76 \%$ of the total length of the routes, and priority for trams at junctions is included on most of them. 
In Poznan, the share of public transport is $42 \%$. Residents here cite the following factors as the main reasons for not using public transport: the convenience of car use, ticket prices and differences in travel time (Badania i opracowanie planu transportowego aglomeracji poznanskiej 2013). The prices of the most frequently purchased season tickets in Poznań (60\% of passengers buy such tickets) are $20-30 \%$ higher than comparable tickets in Warsaw, where these tickets also entitle the users to travel by metro and rail. In Poznań, however, a city railway ticket is $50-60 \%$ more expensive than a city bus or tram ticket.

It can, therefore, be assumed that the share of public transport in Poznań can be increased to a certain extent by changing the pricing policy. The ranking of travel time in third place, relatively low compared to other cities in the ranking of reasons for not using public transport, is the result of the fast tram in Poznań. Its route (more than $8 \mathrm{~km}$ long) is of key importance for travelling in the central and the northern part of the city. The tram has a capacity of 6,000 passengers per hour. The average speed of high-speed trams is $37 \mathrm{~km} / \mathrm{h}$, while with the other public transport vehicles (standard trams and buses) it varies between 19 and $21 \mathrm{~km} / \mathrm{h}$. The further development of the fast tram is planned towards the south and west. Due to the small (2\%) share of the fast tram line in the city tram network, planners from the Poznan Bureau of Transportation Engineering also suggest constructing a bus rapid transit. This is justified as in Poznan bus lanes are only $0.7 \%$ of the total route lengths. The planned improvement in the competitiveness of public transport in terms of travel time should, as already suggested, be accompanied by a change in pricing policy, favouring regular users, with a reduction in the price of season tickets.

Wrockaw has the highest share of cars in the modal split (41\%), which can be explained by the high importance of convenience and travel time as attributes that determine the choice of this mode of transport. The decisive factors for using public transport in Wrocław are ranked as follows: convenience, proximity to the bus stop and short journey time. As the research results indicate, however, the level of satisfaction with the fulfilment of these attributes does not encourage the users of private cars to change their transport behaviour (Kompleksowe badania ruchu we Wroctawiu i otoczeniu 2018). With bus lanes totalling $26.5 \mathrm{~km}$, Wrocław ranks third among Polish cities. However, this is a small length considering that Wrocław does not have an underground or an urban rail network. The lack of alternative means of transport in relation to road vehicles (buses, trams) means that it is necessary to build bus lanes to improve the competitiveness of public transport.

By increasing the speed of travel, bus lanes increase the efficiency of transport (more passenger-kilometres per hour). As a result of the decline in the share of private cars, the increase in the number of passengers increases revenues from tickets and reduces external costs, including those related to traffic and parking, 
accidents and emissions (Badania I opracowania planu transportowego aglomeracji poznańskiej 2013).

In Polish cities, many activities in the management of public transport services do not take into account the importance of particular attributes of these services or do not create an integrated and coherent whole. The lack of such coordination is characteristic of the Gdańsk agglomeration. It is composed of several cities with a combined population of over 1 million inhabitants and has two main centres, Gdańsk (464,000 inhabitants) and Gdynia (246,000 inhabitants). The share of public transport decreased in Gdańsk between 2009 and 2016 by six percentage points (from $38 \%$ to $32 \%$ ), despite the implementation of public transport development projects. New rolling stock was purchased, part of the tracks and overhead lines was modernised, and new tracks with overhead lines were built to one of the largest residential districts. In the next stage, the tram network was extended to the next large residential area. The number of passengers (excluding those using the urban railway), according to the organizer's data, increased from 142 million to 168 million, i.e. by $17 \%$, with an increase in the number of vehicle-kilometres from 12.809 million to 14.404 million, i.e. by 12\% (Public transport in numbers, data for 12 months of 2009, 2010; public transport in numbers, data for 12 months of 2016, 2017). During the implementation of the investment projects, the number of Gdańsk residents increased from 456,000 to 462,000, i.e. by $1.3 \%$. The results of comprehensive traffic research in Gdańsk showed that the mobility indicator in this period increased from 1.92 trips a day to 2.10 , i.e. by $9.3 \%$. The data presented indicate that the increase in the number of passengers in Gdansk was extensive and did not lead to the desired changes in transport behaviour which form the basis of sustainable mobility.

In Gdynia, the second largest city of the Gdańsk agglomeration, the share of public transport in $2008-2018$ decreased from $51.9 \%$ to $41.59 \%$, i.e. by 10.31 percentage points. Pedestrian travel was not considered in the research (Figure 2).

The number of public transport passengers in Gdynia (excluding rail passengers) in 2008-2015 decreased from 85.3 to 75.9 million passengers, i.e. by $12.3 \%$, although city's population increased by $1 \%$, from 245,400 in 2008 , to 247,800 in 2015. The number of vehicle-kilometres of urban transport in Gdynia in the analysed years decreased by $4 \%$. Therefore, the reduction in the number of public transport passengers in Gdynia can be partially explained by the limitation of the number of vehicle-kilometres, and therefore, an action contrary to the policy of sustainable mobility. Based on changes in the modal split, it can be concluded that out of the four scenarios of transport development in Gdynia presented in the Transport Plan, two of which assume sustainable development (Gdańskie badania ruchu 2016), the unsustainable transport scenario is currently being implemented, with a growing share of private cars in the modal split. 
Figure 2. Modal split in Gdynia in 2008-2018

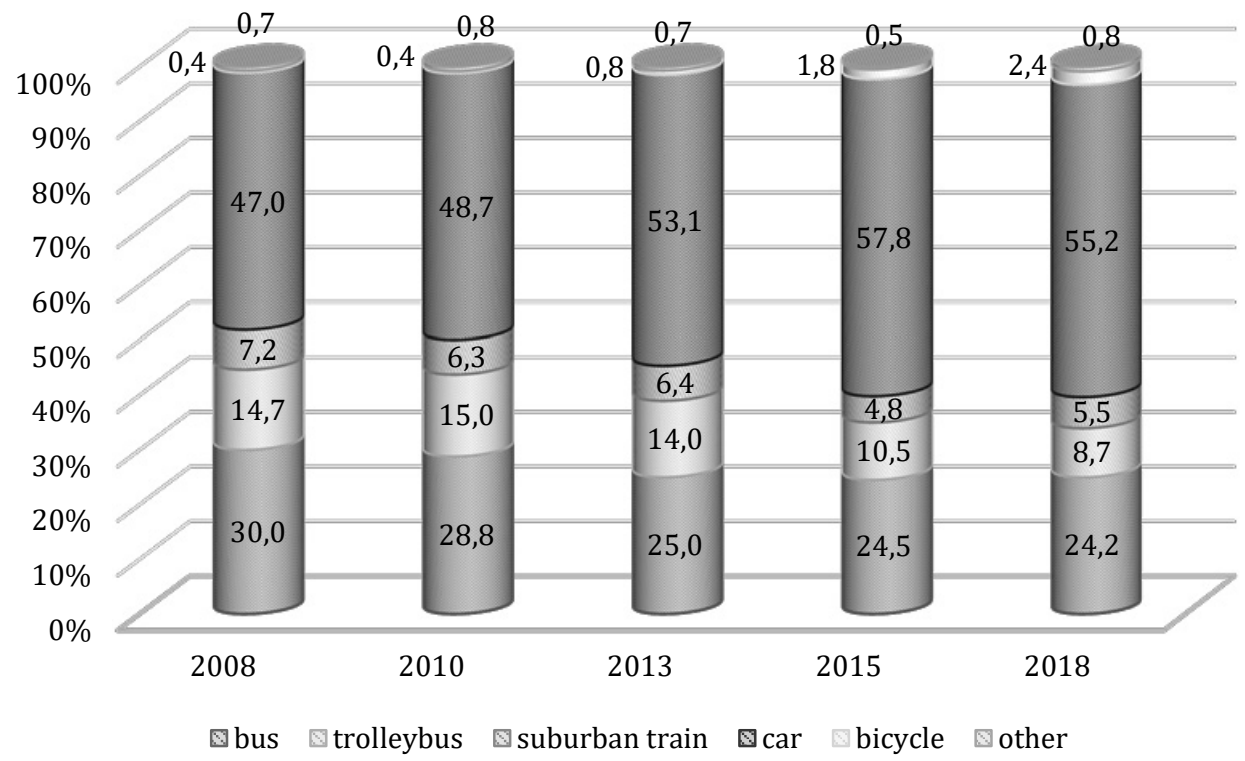

Source: Own study based on Zarząd Komunikacji Miejskiej w Gdyni, Preferencje i zachowania komunikacyjne mieszkańców Gdyni, Raport z badań marketingowych 2015 (2016). Available online: http://www.zkmgdynia.pl/admin/_pliki_/A4_zkmgdynia-PZKMG-raport 2015.pdf (accessed: 7.01.2020); Zarząd Komunikacji Miejskiej w Gdyni, Preferencje i zachowania komunikacyjne mieszkańców Gdyni w 2018 r. https://zkmgdynia.pl/files/Pliki\%20do\%20pobrania\%20\%20inne/ Preferencje\%20i\%20zachowania\%20komunikacyjne\%20mieszka\%C5\%84c\%C3\%B3w\%20Gdyni\%202018.pdf (accessed: 27.10.2020).

In both cities, in order to change transport behaviour, one can identify the following reasons for the increase in the share of cars in urban travel:

- the failure to take effective measures to reduce the public transport travel time perceived by passengers (according to the results of the Gdynia research from 2018, the two most important reasons for choosing a car for urban travel are greater convenience and a shorter travel time by car),

- the incomplete use of the transport capacity of the urban rail system,

- the lack of integration of the various public transport subsystems in the agglomeration.

The "Tristar" Intelligent Traffic System is used in the Gdańsk agglomeration, providing public transport vehicles with priority in traffic in only a few places in the network. There are bus lanes on very short sections in both cities. Research in Gdynia into preferences and transport behaviour (Zarząd Komunikacji Miejskiej w Gdyni 2016) showed that the average travel time by public transport to the workplace (39 minutes) is almost $100 \%$ longer than by car (20 minutes), while 
going to one's place of study (36 minutes) is $80 \%$ ( 16 minutes) longer. The ratios presented have practically not changed in Gdynia since 2000.

The research report for Gdańsk does not allow the calculation of differences in travel time by car and public transport. Taking into account the functioning of faster trams on separated tracks in Gdańsk on the one hand, but also the wider area of this city on the other, it can be assumed that the percentage differences in travel time by car and public transport are similar. Comparing the expected attributes which should characterize public transport services in both cities (Table 3) with real differences in travel time by car and public transport, it can be stated that public transport is less attractive for residents than private cars. According to the results of the research, the most important features expected of public transport are those that are related to travel time.

Table 3. The most important attributes of public transport in Gdańsk and Gdynia

\begin{tabular}{lll}
\hline & Gdańsk (2016) & Gdynia (2018) \\
\hline Directness & Frequency \\
Punctuality & Punctuality \\
Frequency & Directness \\
Availability & Availability \\
Travel time & Low cost \\
Low cost & Speed \\
\hline
\end{tabular}

Source: Gdańskie Badania Ruchu (2016). Available online: https://www.brg.gda.pl/attachments/ article/282/Raport-III.pdf (accessed: 20.03.2019). Zarząd Komunikacji Miejskiej w Gdyni, Preferencje i zachowania komunikacyjne mieszkańców Gdyni w 2018 r. https://zkmgdynia.pl/files/ Pliki\%20do\%20pobrania\%20\%20inne/Preferencje\%20i\%20zachowania\%20komunikacyjne\%20 mieszka\%C5\%84c\%C3\%B3w\%20Gdyni\%202018.pdf (accessed: 27.10.2020).

Meanwhile, the local governments of both cities recognize low travel cost and expanding the number of people entitled to reduced- and free-fare journeys as priority attributes of public transport. A similar policy is also conducted in other cities in Poland, although the effectiveness of such solutions is limited. This is due to the characteristics of the price elasticity of demand for public transport services (Zarząd Komunikacji Miejskiej w Gdyni 2018).

If the reduction of ticket prices or the extension of entitlements to free travel is not accompanied by a noticeable improvement in the quality of services in terms of the most important attributes for passengers, the actions taken may simply lead to wasting public funds. In this context, the decision to considerably expand the number of entitlements to free travel in urban public transport in the year of elections to local authorities in many cities in Poland (2018) should be assessed negatively. In the Gdańsk agglomeration, uncoordinated decisions to extend the range of entitlements to free travel were made individually by the authorities of cities. Attempts to harmonize the range of free travel rights in the entire agglomeration failed and as 
a result, led to the uncoordinated extension of the entitlement to free travel in the election year. The impact of these activities on sustainable mobility objectives has not been adequately analysed, including the main goal - the modal split.

Meanwhile, the example of Tallinn, in which free public transport was introduced in 2013, indicates that such activities do not lead to a significant increase in demand for public transport services (Matulin, Bošnjak, Šimunovič 2009). In the context of the free fare results presented, the actions of local authorities in Poland can be called a social policy, but not a policy of sustainable transport development. Significantly, in Poznan, the Youth City Council (a consultative body of the City Council), consulting the introduction of free public transport in the city for children and adolescents, passed a resolution that ticket prices are at the optimum level and funds allocated for financing free services should be spent on improving the frequency, purchasing new rolling stock and developing infrastructure (EPOMM 2020).

As a result of actions undertaken by local authorities, the revenues from tickets will significantly decrease (in Gdańsk by 2.25 million euro per year). The tendency for public transport revenues from tickets to decrease has been recorded for years, with the share of public transport in modal split unchanged or diminishing. In Polish cities, such a situation was usually accompanied by an increase in costs, resulting mainly from an increase in depreciation costs, due to the intensive exchange of fleet vehicles thanks to the implementation of EU projects, increasing the transport offer, and trade union pressure to increase wages. As a consequence, the revenues/cost ratio of public transport services is reduced. In the 1990s, the revenues from tickets in Polish cities covered $70-75 \%$ of the costs (Urząd Miasta Warszawa 2014). In 2017, revenues covered $30-50 \%$ of costs $42 \%$ (New Urban Agenda 2020). This is a threat to the continuity of the reconstruction processes of the urban transport fleet.

Adjusting the public transport offer to the expectations of current users is no longer sufficient to achieve the goals of a sustainable mobility policy. Steps should be taken to change the transport behaviour of private car users, which would be best achieved by public transport improvements (Carlsson 2003, pp. 41-50). However, this is an expensive operation because car users expect a higher quality of services than public transport passengers (Litman 2016).

The expectation levels of private car users that condition their use of public transport can be lowered by restricting the freedom of use of cars in cities. Such solutions include entry bans or fees for entering central areas and parking fees. The latter, as demonstrated by modelling and empirical studies (Shiftan, Golani 2005), may be effective, especially when they involve a reduction in the number of parking spaces (Chritiansen, Engerbretsen, Fearnley, Hanssen 2017). This is confirmed by the results of research in Gdynia (Figure 3), where inhabitants who have a car cited problems with parking at the destination and parking fees as the most important reasons for choosing public transport when making urban trips. 
Figure 3. Reasons for the choice of public transport in Gdynia by people with a car (percentage of answers) 2018

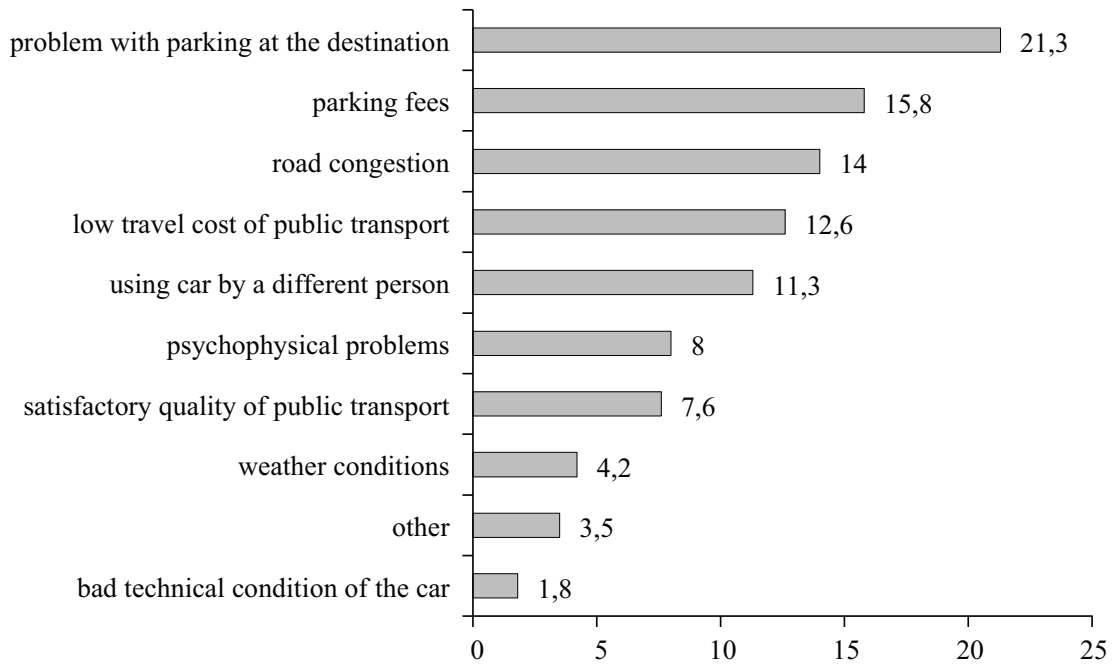

Source: Zarząd Komunikacji Miejskiej w Gdyni, Preferencje i zachowania komunikacyjne mieszkańców Gdyni w 2018 r. https://zkmgdynia.pl/files/Pliki\%20do\%20pobrania\%20\%20inne/Preferencje $\% 20 \mathrm{i} \% 20$ zachowania $\% 20$ komunikacyjne $\% 20$ mieszka $\%$ C5\%84c\%C3\%B3w\%20Gdyni $\% 20$ 2018.pdf (accessed: 27.10.2020).

In Poland, no city has introduced entry fees to the centre because there is no legislation to allow this.

\section{Discussion}

The considerations and results of the research and analysis carried out do not exhaust all the essential aspects related to implementing a sustainable urban mobility policy, raising specific issues for further discussion.

1. Achieving the goals of a sustainable urban mobility policy requires consistency in the objectives and actions adopted in public transport development plans and sustainable mobility plans. The paradox is that making mobility sustainable is a political act and, as such, it is often susceptible to changing political programs. Meanwhile, the condition for the effectiveness of actions taken in the field of sustainable transport policy and the instruments used to influence the changes in residents' transport behaviour is continuity and consistency in action that goes beyond the term of political power from election to election. Therefore, the effectiveness of the policy of sustainable mobility requires not only a proper selection 
of actions and instruments, but also a highly developed political culture, based on an understanding of the coherence of the adopted goals and continuing the initiated activities by each political authority.

2. An effective policy of sustainable mobility requires the prioritisation of the actions undertaken. The authors of this article think that public transport has the most important role in making mobility sustainable in cities and agglomerations. It offers services that are able to "resemble" journeys made with private cars to the greatest extent, so as a result, they are the most likely alternative for them. Therefore, it is necessary to focus on improving the quality of this transport by selecting those attributes that are most important for private car users. The use of half-measures in this respect, succumbing to the pressure of the pro-car lobby and the lack of consistency in the implementation of actions leads to public funds being wasted.

The article does not consider the issues that arise from the restrictions and problems with financing public collective transport, which will certainly affect the achievement of the goals of sustainable mobility. The authors undertook research in this area, but it is still too early to make precise conclusions.

\section{Conclusions}

The idea of sustainable mobility development is adopted in the transport policy of contemporary cities, but implementing this idea requires changes in the structure of urban travel dominated by private cars. As residents of cities expect a high level of quality of life, the policy of sustainable development of mobility should take into account a satisfactory quality of life for city residents.

Striving to ensure an adequate quality of life through a sustainable mobility policy requires the development and implementation of transport plans adapted to this purpose. As part of mobility management, it may be necessary to take steps aimed directly at transport behaviour. It is appropriate to depart from discretion for modern management; it involves setting goals and controlling the effects of their implementation, and using clear and measurable standards and indicators.

Public transport in cities is considered a strong and viable alternative to travel carried out using one's own private car. The basis for effectiveness in implementing the policy of sustainable mobility is the change in transport behaviour, leading to an increase in the share of public transport journeys, cycling and walking. A condition for increasing the share of public transport is to increase the attractiveness of its services. For this purpose, it is necessary to examine the expected attributes of its quality, and determine how the transport offer can be recognised as attractive.

The research hypotheses of the article have been confirmed. 
The appropriate organisation and management of public transport in cities and agglomeration areas enable the use of various mobility management tools and instruments to a greater extent in the pursuit of sustainable mobility.

In cities and agglomerations in Poland, according to the results of research, the most important attributes of the quality of public transport services include those related to travel time. After the completion of certain infrastructure investments, financed to a large extent from the European Union funds, the standard of public transport services has not yet reached the level that corresponds to the full expectations of passengers. As a result, it has not led to the desired changes in the structure of urban travel, in line with the objectives of the policy of sustainable mobility development.

The level of expectations of private car users, which condition their use of public transport, can be reduced by affecting the freedom to use these vehicles in cities through traffic and parking restrictions. In the light of research carried out in Poland, parking fees are an effective tool for limiting the use of private cars. The condition of the effectiveness of this tool, however, is the freedom of local authorities in deciding on the scope of their application and the amount of fees.

Politicians and public transport authorities have more scope to influence travel behaviour than they think, but only if transport interventions are consistent with each other, maintained over a lengthy period, and supported by analytical methods and appraisal frameworks (Goodwin et al. 2004).

Funding: This research received no external funding

Conflicts of interest: The authors declare no conflict of interest.

\section{References}

Badania i opracowanie planu transportowego aglomeracji poznańskiej. Etap I. (2013), http://www.plantap.pl/assets/Uploads/Tekst-etap-I.pdf (accessed: 15.03.2019).

Banister D. (2008), The sustainable mobility paradigm, "Transport Policy”, 15(2), https://doi.org/10.1016/j.tranpol.2007.10.005

Banister D., Stead D. (2004), Impact of information and communications technology on transport, "Transports Reviews", 24(5).

Bauer M.(2015), Dyskusja o zasadności prowadzenia kompleksowych badań ruchu w ramach narodowego spisu powszechnego, "Transport Miejski i Regionalny", 5, https://www.researchgate.net/publication/303646540_DYSKUSJA_ ZASADNOSCI_PROWADZENIA_KOMPLEKSOWYCH_BADAN_RUCHU_W_RAMACH_NARODOWEGO_SPISU_POWSZECHNEGO (accessed: 10.03.2020). 
Berlin.de (2018), Bicycle Routes and Facilities, https://web.archive.org/ web/20080922140453/http:/www.stadtentwicklung.berlin.de/verkehr/ radverkehrsanlagen/en/radwege.shtml (accessed: 7.07.2019).

Biuro Rozwoju Gdańska (2016), Gdańskie Badania Ruchu. https://www.brg.gda. pl/attachments/article/282/Raport-III.pdf (accessed: 20.03.2019).

Braun Kohlová M. (2009), Everyday travel mode choice and its determinants: trip attributes versus lifestyle, http://www.feem-web.it/ess/files/braunkohlova.pdf (accessed: 20.12.2019).

Bryniarska Z., Starowicz W. (2010), Wyniki badań systemów publicznego transportu zbiorowego w miastach, SITK w Krakowie, Kraków.

Campos V.B.G., Ramos R.A.R., e Silva Correia D. de M. (2009), Multi-criteria analysis procedure for sustainable mobility evaluation in urban areas, "Journal of Advanced Transportation", 43(4).

Carlsson F. (2003), The demand for intercity public transport: The case of business passengers, "Applied Economics", 35(1).

Carse A., Goodman A., Mackett R.L., Panter J., Ogilvie D. (2013), The factors influencing car use in a cycle-friendly city: The case of Cambridge, "Journal of Transport Geography", 28.

Cascajo R., Monzón A. (2014), Assessing the passengers' perception of implemented advanced management measures in bus service, http://oa.upm. es/36976/1/INVE_MEM_2014_197741.pdf (accessed: 20.12.2019).

Cats O., Susilo Y.O., Reimal T. (2017), The prospects of fare-free public transport: evidence from Tallinn, "Transportation", 44.

Christiansen P., Engebretsen Ø., Fearnley N., Hanssen J.U. (2017), Parking facilities and the built environment: Impacts on travel behaviour, "Transportation Research Part A: Policy and Practice", 95.

Dill J., Voros K. (2007), Factors Affecting Bicycling Demand: Initial Survey Findings from the Portland, Oregon, "Region. Transportation Research Record" 2031(1), https:/doi.org/10.3141/2031-02

Drechsler W. (2005), The rise and demise of the new public management, "Post-Autistic Economics Review", 33, http://www.paecon.net/PAEReview/ wholeissues/issue33.pdf (accessed: 8.01.2019)

Eboli L., Mazzulla G. (2008), A stated preference experiment for measuring service quality in public transport, "Transport Planning and Technology", 31(5).

EPOMM, http://www.epomm.eu/tems/compare_cities.phtml (accessed: 5.10.2020).

Epomm (2010), Managing Mobility for a Better Future, http://www.epomm.eu/ docs/1499/Max_Brochure_PL.pdf (accessed: 20.10.2019)

Fishman E., Washington S., Haworth N. (2014), Bike share's impact on car use: Evidence from the United States, Great Britain, and Australia, "Transportation Research Part D: Transport and Environment", 31, https://doi. org/10.1016/j.trd.2014.05.013 
Gillis D., Semanjski I., Lauwers D. (2016), How to monitor sustainable mobility in cities? Literature review in the frame of creating a set of sustainable mobility indicators, "Sustainability", 8(1): 29.

Główny Urząd Statystyczny (2016), Bank Danych Lokalnych, https://bdl.stat.gov. pl/BDL/start (accessed: 3.03.2020).

Goldman T., Gorham R. (2006), Sustainable urban transport: Four innovative directions, "Technology in Society", 28(1).

Goodwin P., Cairns S., Dargay J., Hanly M. et al. (2004), Changing travel behaviour. Components, https://www.researchgate.net/publication/32885786 Changing_travel_behaviour\#fullTextFileContent (accessed: 7.03.2019).

Graviter F.J., Forzano L-A.B. (2011), Research Methods for the Behavioural Sciences, Cengage Learning Inc., USA, https://www.cengage.co.uk/ books/9781337613316/ (accessed: 8.03.2019).

Haghshenas H., Vaziri M. (2012), Urban sustainable transportation indicators for global comparison, "Ecological Indicators", 15(1).

Hess D.B. (2017), Decrypting fare-free public transport in Tallinn, Estonia, "Case Studies on Transport Policy", 5(4).

Holmgren J. (2007), Meta-analysis of public transport demand, "Transportation Research Part A: Policy and Practice", 41(10): 1021-1035.

Hughes M. (2012), Measure for Measure: Using Performance Information in Tough Times, APSE, https://www.apse.org.uk/apse/index.cfm/research/current-research-programme/measure-for-measure-using-performance-information-in-tough-times/measure-for-measure-using-performance-information-in-tough-times/ (accessed: 13.01.2019).

IGKM (2013), Raport o stanie komunikacji miejskiej w Polsce za lata 2000-2012, Warszawa, http://docplayer.pl/5735559-Raport-o-stanie-komunikacji-miejskiej-w-polsce-w-latach-2000-2012.html (accessed: 10.01.2019).

IGKM (2018), Komunikacja miejska w liczbach. Dane za 12 miesięcy 2017 r., Warszawa.

Izba Gospodarcza Komunikacji Miejskiej (1998), Komunikacja miejska w liczbach. Dane za 12 miesieccy $1997 \mathrm{r}$., Warszawa.

Joumard R., Gudmundsson H. (2010), Indicators of environmental sustainability in transport: an interdisciplinary approach to methods, https://backend. orbit.dtu.dk/ws/portalfiles/portal/5719272/Joumard+\%26+Gudmundsson+2010+Indicators_EST_May_2010.pdf (accessed: 10.12.2019).

Litman T. (2004), Transit Price Elasticities and Cross-Elasticities, "Journal of Public Transportation", 7(2).

Litman T. (2008), Valuing Transit Service Quality Improvements, "Journal of Public Transportation", 11(2).

Litman T. (2016), When Are Bus Lanes Warranted? Victoria Transportation Policy Institute, https://www.vtpi.org/blw.pdf (accessed: 7.03.2019). 
Matulin M., Bošnjak I., Šimunovič L. (2009), Different approaches to the modal split calculation in urban areas [Internet], Conference proceedings of ICTS 2009: "Transport, Maritime and Logistics Science", https://bib.irb.hr/datoteka/414598.Matulin20Bosnjak20Simunovic.pdf (accessed: 19.03.2019).

Ministry of Funds and Regional Policy (2015), National Urban Policy 2023, Warsaw. Ministry of Infrastructure (2002), State Transport Policy for the years 2006-2025, Warsaw.

Młodzieżowa Rada Miasta Poznania (2018), Uchwała nr LXVI/2/2018 Młodzieżowej Rady Miasta Poznania, Poznań.

Mobility in Cities. Database. (2018), https://www.uitp.org/MCD (accessed: 20.07.2019).

New Urban Agenda, https://habitat3.org/the-new-urban-agenda/ (accessed: 5.10.2020).

Nicolas J.P., Pochet P., Poimboeuf H. (2003), Towards sustainable mobility indicators: Application to the Lyons conurbation, "Transport Policy", 10(3).

Nykvist B., Whitmarsh L. (2008), A multi-level analysis of sustainable mobility transitions: Niche development in the UK and Sweden, "Technological Forecasting and Social Change", 75(9).

Okraszewska R., Romanowska A., Wołek M., Oskarbski J., Birr K., Jamroz K. (2018), Integration of a multilevel transport system model into sustainable Urban mobility planning, "Sustainability", 10(2), 479: 1-20.

Parasuraman A., Zeithaml V., Berry L. (1988), SERVQUAL: A Multiple-Item Scale for Measuring Consumer Perceptions of Service Quality, "Journal of Retailing", 64(1).

Potocki K., Brocato R.C. (1995), A system of management for organisational improvement, "Journal Hopkins APL Technical Digest", 16(04).

Pticina I. (2011), The methodology of data collection about public transport service quality. The 11th International Conference, "Reliability and statistics in Transportation and Communication", http://www.tsi.lv/sites/default/ files/editor/science/Publikacii/RelStat_11/sess_3_pticina_ed.pdf (accessed: 14.02.2020).

Rada Miasta st. Warszawy (2014), Plan zrównoważonego rozwoju transportu zbiorowego dla m. st. Warszawy z uwzględnieniem transportu zbiorowego organizowanego na podstawie porozumień z gminami sasiadujacymi, http:// transport.um.warszawa.pl/sites/default/files/PlanTransportowy_tekst ze spisem terści_0.pdf (accessed: 15.07.2019).

Rada V.D. de, Martín V.M. (2014), Random Route and Quota Sampling: Do They Offer Any Advantage over Probably Sampling Methods?, "Open Journal of Statistics", 04(05).

Redman L., Friman M., Gärling T., Hartig T. (2013), Quality attributes of public transport that attract car users: A research review, "Transport Policy", 25. 
Reichert A., Holz-Rau C. (2015), Mode Use in Long-Distance Travel, "Journal of Transport Land Use", 8(2).

Rietveld P. (2005), Six reasons why supply-oriented indicators systematically overestimate service quality in public transport, "Transport Reviews", 25(3).

Samochody osobowe zarejestrowane w Polsce (2017), http://www.cepik.gov.pl/ dla-obywateli/usluga-statystyczna (accessed: 10.08.2019).

Shiftan Y., Golani A. (2005), Effect of Auto Restraint on Travel Behaviour, "Transportation Research Record", 1932(1).

Starowicz W. (2001), Ksztaltowanie jakości ustug przewozowych w miejskim transporcie zbiorowym, Szczecin: Wydawnictwo Naukowe Uniwersytetu Szczecińskiego.

Steg L. (2003), Can Public Transport Compete With The Private Car?, "IATSS Research", 27(2).

Suchorzewski W., Rozkwitalska C. (1997), Raport o stanie komunikacji miejskiej w 1996 roku, Sterowanie i zarzadzanie ruchem w komunikacji miejskiej, http://www.igkm.pl/site/publikacje/pub_raport96.pdf (accessed: 10.08.2019).

Tafidis P., Sdoukopoulos A., Pitsiava-Latinopoulou M. (2017), Sustainable urban mobility indicators: Policy versus practice in the case of Greek cities, "Transportation Research Procedia", 24.

UITP (2002), Public transport for sustainable mobility, https://www.uitp.org/public-transport-sustainable-mobility (accessed: 13.03.2020).

UN (2015), We are transforming the world: the 2030 Agenda for Sustainable Development, Resolution adopted by the UN General Assembly on September 25, UN on October 21, 2015 A / RES / 70/1.

United Nations (2015), Sustainable Development Goals UNDP.

Urząd Miasta Kraków (2013), Kompleksowe badania ruchu w Krakowie, https://www. bip.krakow.pl/zalaczniki/dokumenty/n/207255/karta (accessed: 10.01.2019).

Urząd Miasta Warszawa (2016), Warszawskie Badanie Ruchu 2015 wraz z opracowaniem modelu ruchu, http://transport.um.warszawa.pl/sites/default/files/ WBR 2015 SYNTEZA POL.pdf (accessed: 7.01.2019).

Urząd Miasta Wrocław (2018), Kompleksowe badania ruchu we Wroctawiu i otoczeniu, http://bip.um.wroc.pl/artykul/565/37499/kompleksowe-badania-ruchu-we-wroclawiu-i-otoczeniu-kbr-2018 (accessed: 7.02.2020).

WBCSD (2015), Methodology and indicator calculation method for Sustainable Urban Mobility, WBCSD - World Business Council for Sustainable Development, https//www.eltis.org/resources/tools/metodology-and-indicator-calculation-method-sustainable-urban-mobility (accessed: 7.11.2019).

Wollmann H. (2004), Local government reforms in Great Britain, Sweden, Germany and France: Between multi-function and single-purpose organisations, "Local Government Studies", 30(4). 
Xu S.J., Chow J. (2018), A longitudinal study of bike infrastructure impact on bikeshare system performance, Researchgate.Net. (January): 1-20, https://www. researchgate.net/profile/Susan_Xu5/publication/320273966_A_longitudinal_study_of_bike_infrastructure_impact_on_bike-share_system_performance/links/5a219ec6a6fdcc8e8664f56b/A-longitudinal-study-of-bike-infrastructure-impact-on-bike-share-system (accessed: 6.07.2019).

Zarząd Komunikacji Miejskiej w Gdyni (2016), Preferencje i zachowania komunikacyjne mieszkańców Gdyni Raport z badań marketingowych 2015, http:// www.zkmgdynia.pl/admin/_pliki_/A4_zkmgdynia-PZKMG-raport2015. pdf (accessed: 7.01.2020).

Zarząd Komunikacji Miejskiej w Gdyni (2019), Preferencje i zachowania komunikacyjne mieszkańców Gdyni w 2018 r., https://zkmgdynia.pl/files/Pliki\%20do\%20pobrania\%20-\%20inne/Preferencje\%20i\%20zachowania\%20 komunikacyjne $\% 20$ mieszka\%C5\%84c\%C3\%B3w\%20Gdyni\%202018.pdf (accessed: 27.10.2020).

Ziefle M., Wilkowska W. (2015), What makes people change their preferences in public transportation - Opinions in different user groups. In: Lecture Notes of the Institute for Computer Sciences, Social-Informatics and Telecommunications Engineering, LNICST.

\section{Summary}

The assumptions and goals of sustainable urban mobility are defined in global and national documents, for example, the United Nations 2030 Agenda and in the Transport Policy of the State of Poland for 2006-2025. Achieving these goals is a long process. Tools and actions have been identified that play a fundamental role in achieving sustainable mobility, and various methods of measuring the effectiveness of these activities have been presented and compared.

The article presents the following research hypotheses:

- achieving the goals of sustainable mobility through the development of the public transport offer requires the use of modern management methods,

- it is necessary to identify the main attributes of public transport that determine the use of this type of transport and to finance those elements of the transport offer that correspond to these attributes.

The aim of the article is to assess the role of public transport as an element of sustainable mobility and to explain the reasons for unsatisfactory policy effects in Poland. 
Analysing the effectiveness of actions and tools used in Polish cities in achieving the goals of sustainable mobility, the processes of management in public transport and shaping the attributes of transport services and technical solutions were selected for the analysis. The analysis was carried out on the example of selected Polish cities.

On the basis of the conducted research, the authors formulated conclusions:

- the idea of sustainable mobility development is an element of the transport policy of modern European cities,

- achieving sustainable development requires changes in the structure of urban transport,

- effective implementation of a sustainable mobility policy leads to changes in transport behaviour,

- the condition for increasing the share of public transport is to increase the attractiveness of its services.

Detailed conclusions were defined in relation to selected Polish cities, in particular Gdańsk and Gdynia. The use of public transport by people who can travel by car can be increase by affecting the freedom to use passenger cars in cities through traffic and parking restrictions. The most effective tool that limits the use of private cars turns out to be parking fees in the city.

Conclusions from the conducted research allowed us to confirm the research hypotheses of the article.

Keywords: public transport, sustainable mobility, transport policy

\section{Streszczenie}

\section{Publiczny transport miejski jako narzędzia polityki zrównoważonej mobilności - na przykładzie Polski}

Założenia i cele zrównoważonej mobilności miejskiej określone są w dokumentach globalnych i krajowych, np. Agendzie ONZ 2030 oraz Polityce transportowej Państwa Polskiego na lata 2006-2025. Osiągnięcie tych celów to długi proces. Zidentyfikowano narzędzia i działania, które odgrywają fundamentalną rolę w osiągnięciu zrównoważonej mobilności. Przedstawiono i porównano różne metody pomiaru efektywności tych działań.

W artykule przedstawiono następujące hipotezy badawcze:

- osiągnięcie celów zrównoważonej mobilności poprzez rozwój oferty komunikacji zbiorowej wymaga zastosowania nowoczesnych metod zarządzania, 
- konieczne jest zidentyfikowanie głównych atrybutów transportu publicznego determinujących korzystanie $\mathrm{z}$ tego rodzaju transportu oraz sfinansowanie tych elementów oferty przewozowej, które odpowiadają tym atrybutom.

Celem artykułu jest ocena roli transportu publicznego jako elementu zrównoważonej mobilności oraz wyjaśnienie przyczyn niezadowalających efektów polityki w Polsce.

Analizując skuteczność działań i narzędzi stosowanych w polskich miastach w osiąganiu celów zrównoważonej mobilności, do analizy wybrano procesy zarządzania w transporcie publicznym oraz kształtowania atrybutów usług transportowych i rozwiązań technicznych. Analizę przeprowadzono na przykładzie wybranych polskich miast.

Na podstawie przeprowadzonych badań autorzy sformułowali wnioski:

- idea zrównoważonego rozwoju mobilności jest elementem polityki transportowej nowoczesnych miast europejskich,

- osiągnięcie zrównoważonego rozwoju wymaga zmian w strukturze transportu miejskiego,

- skuteczna realizacja polityki zrównoważonej mobilności prowadzi do zmian zachowań transportowych,

- warunkiem zwiększenia udziału transportu zbiorowego jest podniesienie atrakcyjności jego usług.

Szczegółowe wnioski określono w odniesieniu do wybranych polskich miast, w szczególności Gdańska i Gdyni. Korzystanie z transportu publicznego przez osoby, które mogą podróżować samochodem, można ograniczyć, wpływając na swobodę korzystania z samochodów osobowych w miastach poprzez ograniczenia ruchu i parkowania. Najskuteczniejszym narzędziem ograniczającym korzystanie z prywatnych samochodów okazują się opłaty parkingowe w mieście.

Wnioski z przeprowadzonych badań pozwoliły potwierdzić hipotezy badawcze artykułu.

Słowa kluczowe: transport publiczny, zrównoważona mobilność, polityka transportowa 